\title{
Gender Differences in Gifted and Average-Ability Students
}

\section{Comparing Girls' and Boys' Achievement, Self-Concept, Interest, and Motivation in Mathematics}

\author{
Franzis Preckel \\ University of Trier, Germany \\ Thomas Goetz \\ University of Konstanz, Germany, and Thurgau University of Teacher Education, Kreuzlingen, Switzerland \\ Reinhard Pekrun \\ University of Munich, Germany \\ Michael Kleine \\ University of Regensburg, Germany
}

\begin{abstract}
This article investigates gender differences in 181 gifted and 181 average-ability sixth graders in achievement, academic self-concept, interest, and motivation in mathematics. Giftedness was conceptualized as nonverbal reasoning ability and defined by a rank of at least $95 \%$ on a nonverbal reasoning subscale of the German Cognitive Abilities Test. Mathematical achievement was measured by teacher-assigned grades and a standardized mathematics test. Self-concept, interest, and motivation were assessed by questionnaire. In both ability groups, boys earned significantly higher test scores but there were no gender differences in grades. Girls scored lower on measures of academic self-concept, interest, and motivation. Gender differences were larger in gifted than in average-ability students. Ability group differences for self-concept and interest were only found for boys in favor of the gifted. Results support the assumption that gender differences in self-concept, interest, and motivation in mathematics are more prevalent in gifted than in average-ability students.
\end{abstract}

Putting the Research to Use: What can educators do to increase the number of gifted females choosing academic courses and careers in domains related to mathematics, the inorganic sciences, and engineering? First of all, they have to know the reasons why gifted as well as nongifted females are underrepresented in these areas. Students' choices of mathematical careers largely depend on the way they react to statements like the following ones: "It is easy for me to solve mathematical problems" (academic self-concept), "I am interested in mathematics" (interest), "I want to learn as much as possible from math class" (motivation). However, in spite of earning equally good grades in mathematics as boys, girls report lower mean levels of academic self-concept, interest, and motivation. This holds for gifted students as well as for students of average ability. In samples of sixth-grade students, we found that this gender gap is even more pronounced in gifted than in average-ability students. Thus, it seems very important to foster females', and particularly gifted females', positive attitudes toward mathematics. One possibility for doing so would be to foster gifted female students' attributions to ability when they receive good grades. In addition, interventions should not only focus on the girl herself but also on environmental factors including parents, teachers, the peer group, and administrative planning.

Keywords: mathematics; giftedness; gender differences; academic self-concept; interest; motivation

$\mathrm{T}$ There are numerous studies on gender differences in mathematics and related areas with samples of intellectually gifted students (e.g., Gallagher \& Kaufmann, 2005; Heller \& Ziegler, 1996; Lubinski,
Benbow, \& Morelock, 2000; see also Ziegler, 2004). However, because many of these studies have investigated participants of special programs for the gifted these findings cannot be generalized to other groups 
of gifted students. First, students in special programs are aware of their ability because of their selection to the program. This awareness, in turn, likely influences academic self-concept and motivation. Furthermore, in most of the extant studies, suitable control groups were lacking. Because it is a replicated finding that the intellectually gifted, on average, are from families with higher socioeconomic status (SES; e.g., Roznowski, Reith, \& Hong, 2000), the lack of control groups matched for SES makes it difficult to disentangle the influence of SES. This study avoids these limitations by sampling gifted students and a control group-both drawn from a large unselected sample. The sample comprised gifted and control students from regular mixedability classes of a large stratified random sample.

Recent research on gender differences in mathematics produced the paradoxical finding that girls still often hold dysfunctional perceptions of themselves as learners in mathematics (Leder, 2004) despite the fact that their achievement has increased in past years. This also is true for high-achieving girls and girls with high potential for achievement in mathematics. Most studies on gender differences in the intellectually gifted are, explicitly or implicitly, concerned with what Enman and Lupart (2000) called 'talented female students' resistance to science" (p. 161). In the general population, fewer women than men chose academic courses or careers in mathematics, the inorganic sciences, and engineering. This also holds true for women of high scientific ability. Research has further documented that the underrepresentation of women in these fields grows with increasing scientific ability (Zorman \& David, 2000).

One explanation for these gender differences is ability differences because there is a larger proportion of males than females with very high ability in the inorganic sciences (Lubinski et al., 2000; Lubinski \& Humphreys, 1990; Stumpf \& Stanley, 1998). Alternative explanations conceptualize gender differences from a perspective that stresses social influences (e.g., socialization practices, gender roles) and related psychological factors (e.g., values and preferences, competence beliefs, interests). A popular model for the analysis of educational and vocational choice in the

Authors' Note: This study was supported by grants from the German Research Foundation to the third author (DFG; PE 320/111, PE 320/11-2, PE 320/11-3, PE 320/11-4). Address correspondence to Franzis Preckel, University of Trier, Department of Psychology, D-54286 Trier, Germany; phone: +49 651201 4520; fax:+49651201 4578; e-mail: preckel@uni-trier.de.

Note: This article was accepted under the editorship of Paula Olszewski-Kubilius. math-science domain is Eccles's (1983) model of achievement-related choices, which has also been applied to the gifted (Eccles \& Harold, 1992). This is an expectancy-value model of motivation for achievementrelated choices that addresses two critical variables: (a) expectations for success and failure, which are affected by an individual's specific beliefs and interpretations of ability, aptitudes, tasks, and past events and (b) subjective task value, which is influenced by an individual's affective memory of past events as well as the beliefs and behavior of significant others (see also Pekrun, 1993). In particular, parents' perceptions of their children's abilities are assumed to be major determinants of children's competence beliefs and values (i.e., Eccles, 1993; Jacobs \& Eccles, 1992). According to Eccles and colleagues, lower participation rates of females in the math-science domain (courses and vocations) result from girls', as compared to boys', lower rating of their abilities in math and science and from girls' lower rating of the value of participating in related fields (Eccles, Adler, \& Meece, 1984).

Another model that explains gender differences in the gifted in mathematics and science was developed by the researchers associated with the Study of Mathematically Precocious Youth (Lubinski et al., 2000) at Johns Hopkins University. Based on the theory of work adjustment (Dawis \& Lofquist, 1984), this approach stresses factors related to personal choice including preferences and values as well as ability differences (both as having some natural base) instead of viewing culturally imposed internal and external barriers as the primary cause of gender differences (Lubinski et al., 2000). The authors argued that social influence alone cannot be responsible for gender differences because the male advantage is found only for specific mathematical tasks, whereas females do equally well or even better on other mathematical tasks.

\section{Gender Differences in Mathematics}

Mathematical ability. Meta-analytic findings indicate that gender differences in numerical and nonverbal reasoning, which are critical predictors of mathematical competence, are minimal in unselected samples (Hyde, Fennema, \& Lamon, 1990). In a large normative sample of 5 th- to 10th-grade students (Jäger et al., 2006), gender differences in numerical and nonverbal reasoning were found in favor of male participants, but these differences explained no more than $0.3 \%$ to $1 \%$ of the variance in Intelligence Quotient (IQ) scores. However, another picture emerges in samples of gifted individuals. There is an overrepresentation of males 
among the mathematically gifted. This gender difference can be detected at a very young age (Halpern, 2000) and becomes more pronounced at higher levels of education. For the top $5 \%$ of 7 th- and 8 th-grade students in talent searches, a male-to-female ratio of 13:1 has been reported (Benbow \& Stanley, 1983). In a more recent publication, Brody, Barnett, and Mills (1994) reported a male-to-female ratio of 6:1.

Looking at performance differences-typically assessed with standardized mathematics tests-metaanalytic research indicates that most gender differences are small and steadily declining in samples from the general population (Hyde et al., 1990; Leahey \& Guo, 2001). In their meta-analytic study, Hyde et al. (1990) found a slight age trend implying performance differences in favor of males that start to occur after primary school and become most pronounced at the high school and university levels. However, findings were dependent on the type of task: Males scored higher on problem solving, females scored higher on mental arithmetic tasks, and there were no gender differences found for computational tasks (Educational Testing Service, 1987; Hyde et al., 1990). Similar findings were reported for mathematically gifted 12- to 13-year-old students (Benbow \& Lubinski, 1993).

The Trends in International Mathematics and Science Study (formally called Third International Mathematics and Science Study) showed that gender differences for eighth graders in mathematics, assessed between 1990 and 2003, were quite small (C. E. Freeman, 2004) and declined over the years (Hanna, 2000). However, in the 2003 cycle of the Programme for International Student Assessment (PISA), which investigates mathematical literacy in 15-year-old students, gender differences in mathematics in favor of males were found in almost all of the participating countries (Organization for Economic Cooperation and Development [OECD], 2004).

For students' school grades, it has been documented that females, throughout their school careers, earn higher grades than do males in most academic courses, including advanced mathematics (i.e., J. Freeman, 2004; Halpern, 2000; Hosenfeld, Köller, \& Baumert, 1999). For the intellectually gifted, results are less consistent. Some studies documented higher grades in math and science for gifted males (Colangelo et al., 1996), some studies found no gender differences (for 10thgrade students: Schober, Reimann, \& Wagner, 2004; Roznowski et al., 2000), and others found that gifted males had lower grades in math than did gifted females (students between ages 7 and 18: J. Freeman, 2004; Lubinski \& Benbow, 1992; 5th- to 10th-grade students:
Jäger et al., 2006). Thus, there are no consistent findings suggesting a male or female lead with respect to grades in mathematics. In part, these inconsistent findings may be traced to cultural differences in administrative planning, style and content of school curriculum, and teaching practices (J. Freeman, 2003, 2004).

In sum, in the general population, gender differences in numerical and nonverbal reasoning, which are critical aptitudes for achievement in mathematics, as well as gender differences in mathematics performance, including teacher-assigned school grades, are minimal. The age trend of better performance of males as compared to females reported by Hyde et al. (1990) refers to specific tasks. In many countries, males show better performance in tasks that call for mathematical literacy. For the gifted, there is an overrepresentation of males within the group identified as highly gifted. However, the disparities found for the male-to-female ratio at high ability levels cannot solely explain why females avoid careers in the inorganic sciences to such a large extent. In addition, even those females who show extraordinary scientific ability are entering the math-science pipeline less frequently than are their male counterparts (Kerr \& Robinson Kurpius, 2004; Lubinski \& Benbow, 1992). Thus, gender differences in career choice can hardly be explained solely by ability differences.

In the following section, we describe findings for gender differences in math-related competence beliefs, interest, and motivational variables (i.e., goal orientation). First we report results for unselected samples for each of these constructs. Then we report results found for intellectually gifted students.

Competence beliefs in mathematics. Gender differences of academic self-concept in mathematics are consistent with traditional gender role expectations and stereotypes, showing higher scores in mathematics selfconcepts for males (e.g., for elementary school students: Eccles, Wigfield, Harold, \& Blumenfeld, 1993; Marsh \& Yeung, 1997; see also the meta-analysis by Wilgenbusch \& Merrill, 1999) as well as higher scores in math selfefficacy for males (e.g., Pajares \& Miller, 1994; for $15-$ year-old students: OECD, 2004; Pekrun \& Zirngibl, 2004). Gender differences in math-related competence beliefs in favor of boys have been documented as early as the first grade (Eccles et al., 1993; Wigfield et al., 1997) and have been found to be relatively stable over the school years (Marsh, 1993). Girls, more often than boys, think they have to work harder to achieve good results in mathematics (Lupart, Cannon, \& Telfer, 2004) 
and show less self-confidence in their math ability (students in the last stages of secondary education: Baumert, Bos, \& Lehmann, 2000).

In the PISA 2003 assessment of 15-year-old students in countries of the OECD, effect sizes between .14 and .72 were reported for gender difference in academic self-concept in mathematics, in favor of boys (Pekrun \& Zirngibl, 2004). Higher self-perception of math ability in boys was found to be relatively independent of performance history (e.g., Frome \& Eccles, 1998), achievement level, and ability (12th-grade students and undergraduate university students: Holling \& Preckel, 2005). Thus, in both gifted and nongifted groups, boys have higher self-perceptions of their math abilities than do girls (students in the last stages of secondary education: Fox, Engle, \& Paek, 2001; Terwilliger \& Titus, 1995; Ziegler, Heller, \& Broome, 1996; Zorman \& David, 2000).

Mathematics interest. In the PISA 2003 assessment of ninth graders, male students in all participating countries reported higher interest in math than did female students (although the mean effect size was rather small; $d=.21$; Pekrun \& Zirngibl, 2004; OECD, 2004). The Trends in International Mathematics and Science Study also found higher interest in math and science for boys (students in the last grades of secondary education: Baumert et al., 2000; see also Lupart et al., 2004).

There are fewer gender-stereotyped interest patterns found among the gifted as compared to average-ability students in nonacademic domains (10th-grade students: Lubinski \& Humphreys, 1990). For academic domains, however, gender differences are found to be similar to those observed in unselected groups: Gifted males show more interest in physics, whereas gifted females show higher interests in social issues, literature, and the arts (Lubinski \& Humphreys, 1990). With respect to the Holland model (Holland, 1997), the main interests of mathematically talented adolescent males lie in the investigative and realistic sectors. In contrast, mathematically talented adolescent females are socially and aesthetically oriented and have interests that are more evenly divided among investigative, social, and artistic pursuits (Lubinski et al., 2000). Mathematically talented females are attracted to social values (people dimension), which are negatively correlated with interests in inorganic science, whereas mathematically talented males are theoretically oriented in their study values (things dimension) (Achter, Lubinski, \& Benbow, 1996).

Motivation in mathematics. Throughout the entire ability range, girls demonstrate lower levels of motivation with respect to mathematics than do boys (students in 6th, 9th, and 11th grades: Skaalvik \& Skaalvik, 2004;Zorman \& David, 2000). Recent research on academic motivation has focused on students' academic goal orientations, distinguishing between mastery goals (pertaining to the development of competence through task mastery) and performance goals (pertaining to achieving more than others or no less than others) (Elliot \& Harackiewicz, 1996). Research has documented that male middle school students tend to have higher performance goal orientations than do their female counterparts (Pajares, Britner, \& Valiante, 2000). In mathematics, it was found that males have higher performance goals than do females (15-year-old students: Pekrun \& Zirngibl, 2004; students in 6th, 9th, and 11th grades: Skaalvik \& Skaalvik, 2004). In a meta-analytic study, Finsterwald and Ziegler (2002) found higher performance goal orientation in intellectually gifted boys as compared with intellectually gifted girls $(d=.23)$, whereas no gender differences were found for mastery goal orientation.

To summarize, mean gender differences in mathematical ability are of negligible size in unselected student populations. However, for students with very high levels of mathematical ability, there is an overrepresentation of males. In the general as well as the gifted populations, gender-related differences in math performance are task specific: Boys show better mathematical problem-solving abilities than do girls, whereas girls show a slight advantage in mental arithmetic. Females seem to get better grades at school, but males outperform females on tasks that require mathematical literacy. Furthermore, in the general as well as the gifted populations, males show higher mathematics-related competence beliefs, a stronger interest in math, and a stronger performance goal orientation in mathematics than do females.

\section{Research Questions and Hypotheses}

The purpose of this study was to investigate gender differences in gifted students with respect to achievement, self-concept, interest, and motivation (i.e., mastery and performance goal orientation) in mathematics. Furthermore, we aimed to explore the extent to which differences in these variables are specific to gifted students. Therefore, gender differences in gifted students were compared to gender differences in average-ability students.

The study was designed to avoid the two drawbacks of previous research. One problem of prior studies on the gifted, including studies on gender differences, was that samples were drawn from specialized programs for the gifted in which participants 
knew about their abilities and received specialized educational treatments such as accelerated instruction, advanced math courses, or math enrichment options (e.g., summer schools). Therefore, it is difficult to generalize findings to other groups of gifted individuals. Second, most of the studies cited above lacked suitable control groups. To avoid these problems, students in this study were recruited from regular classrooms. Furthermore, a sample of gifted students and a sample of average-ability students were included. A large, representative sample of unselected classrooms was used to recruit these two groups.

Our hypotheses on gender differences in achievement and affective variables were derived from the extant research literature, as described above. Succinctly stated, our hypotheses were as follows:

Hypothesis 1a: There are no gender differences in grades in mathematics in gifted or in average-ability students.

Hypothesis $1 \mathrm{~b}$ : Males show higher mathematical competences in terms of mathematical literacy than do females among both gifted and average-ability students.

Hypothesis 2: There are gender differences in academic self-concept, interest, and motivation in mathematics in both gifted and average-ability students. Males have (a) a higher academic self-concept and (b) more interest in mathematics. Males and females show (c) similar levels of mastery goal orientation in mathematics but (d) males show a stronger performance goal orientation in mathematics than do females.

\section{Method}

\section{Definition of Giftedness}

In this study, giftedness was conceptualized as an ability that can manifest itself in extraordinary achievement (performance) but does not necessarily do so in all individuals at all points of time (Sternberg \& Davidson, 2005). Generally, the definition of giftedness used in empirical studies is not only a conceptual issue but can also be influenced by context of the study. In many educational contexts where the selection of gifted students for special programs is a major concern, a definition of giftedness from an aptitude perspective that takes into account not only cognitive abilities but also domain specific knowledge and academic accomplishments is useful (Lohman, 2005). This study, however, does not aim to investigate the selection of students for educational programs but focuses on basic research questions pertaining to math-related gender differences.

In accord with Preckel and Thiemann (2003), who concluded that differences between average and high intellectual ability students are best identified by use of item material that shows high loadings on the $g$ factor or a factor of fluid intelligence (such as items of reasoning tests), we chose a measure of nonverbal reasoning that is an established marker of fluid intelligence (Carroll, 1993) and plays an important role for learning in math and science comparable across different school settings. We did not use measures of verbal or quantitative reasoning because these measures reflect more crystallized intelligence (i.e., verbal and numerical knowledge) than figural measures and are more closely aligned with type of schooling (Jäger et al., 2006).

\section{Participants}

The sample consisted of 181 gifted and 181 nongifted participants. Both groups were drawn from a random stratified sample of 2,059 sixth-grade students that is representative with respect to SES, school type, rural versus urban population, and gender. ${ }^{1}$ This sample of students (50.02\% female) came from 81 classes in 42 schools from all tracks of the German three-track education system. In this school system, after fourth grade, students are placed into one of three tracks (lower, middle, and top track) according to their level of achievement. Of note, "top track" does not refer to a track reserved for gifted students because up to $50 \%$ of the general student population attend this track.

The mean age of the sample was 12.77 years $(S D=$ 0.52 ; range $=11.17$ to 15.42 ). The gifted were drawn from the random stratified sample in accordance to a cut-off score on the nonverbal reasoning test above $95 \%$. The sample of average-ability students was recruited as follows: For each gifted student, a nongifted student (nonverbal IQ within the range of $1 \mathrm{SD}$ from the mean of IQ 100) was drawn who had the same gender as the gifted student, came from the same school class, and whose family had an equivalent SES.

The distribution of all participants (gifted and parallel) across school tracks was as follows: $56.4 \%$ attended the top track, $33.1 \%$ the middle track, and $10.5 \%$ the lower track. For the gifted students, there were no gender differences as to school track attended (KolmogorovSmirnov $Z=.92, p=.37$ ). In Table 1 , the distributions of nonverbal reasoning scores and SES are described for the two groups. SES was categorized in accordance to the Erikson-Goldthorpe-Portocarero classification of 
Table 1

Descriptive Statistics for Nonverbal Reasoning and Socioeconomic Status (SES) for Gifted and Average-Ability Students as Well as Results of Statistical Tests ( $t$ Test, Wilcoxom) for the Equivalence of the Groups ( $N=181$ in each group; $49.2 \%$ female)

\begin{tabular}{lccc}
\hline & Gifted & Average Ability \\
\hline Nonverbal reasoning $M(S D)$ & $127.10(0.77)$ & $103.56(10.36)$ & \\
SES \% & 9.5 & 7.5 & 20.8 \\
1 & 19.0 & 27.7 & \\
2 & 23.2 & 4.0 & \\
3 & 8.9 & 23.7 & \\
4 & 21.4 & 16.2 \\
5 & 17.9 & & \\
6
\end{tabular}

Note: Nonverbal reasoning scale of the KFT 4-12+R; Intelligence Quotient scale with $M=100$ and $S D=15$. SES $1=$ higher-grade professionals, administrators, officials; managers in large industrial establishments; large proprietors. SES $2=$ lower-grade professionals, administrators, officials; higher-grade technicians; managers in small business and industrial establishments; supervisors of nonmanual employees. SES 3 = routine nonmanual employees in administration and commerce, sales personnel, other rank-and-file service workers. SES 4 = small proprietors; artisans (etc.) without employees; farmers, smallholders; self-employed fishermen. SES $5=$ lower grade technicians, supervisors of manual workers, skilled manual workers. SES $6=$ semiskilled and unskilled manual workers (not in agriculture), agricultural workers.

occupations (Erikson, Goldthorpe, \& Portocarero, 1979), which takes into account title of occupation, full- versus part-time occupation, and functions and powers related to the occupation.

As defined by the sampling procedure, the gifted and the parallel samples differed significantly in nonverbal reasoning ability but did not differ with respect to SES. Compared with the total, unselected sample, the gifted sample came from families with higher $\operatorname{SES}(Z=-2.22, p=.03)$. There were no gender differences for the gifted in SES (Kolmogorov-Smirnov $Z=1.30, p=.07$ ).

\section{Measures}

Nonverbal reasoning ability. Nonverbal reasoning ability was assessed with the respective scale of the KFT 4-12+R (Heller \& Perleth, 2000; $M=100 ; S D=$ 15). The KFT $4-12+\mathrm{R}$ is a German adaptation of the Cognitive Abilities Test developed by Thorndike and Hagen (1971), last revision in $1996 .^{2}$ In Germany, the KFT $4-12+\mathrm{R}$ is one of the most frequently used intelligence tests and also is widely used in research on giftedness and education. For the identification of high potential in math and science, usually the nonverbal reasoning scale is used (e.g., Ziegler et al., 1996). Both in the standardization sample and in the sample of this study, there were no gender differences on this scale of the KFT 4-12+R, suggesting that nonverbal reasoning as assessed by this scale is not confounded with spatial abilities that have been found to be gender linked (with higher scores for males). The scale contains 25 figural analogy multiple-choice items that ask participants to make inferences, deductions, and extrapolations pertaining to figural stimuli (inductive reasoning; Carroll, 1993). The test was presented in a paper-and-pencil format. Time limits were followed as outlined in the test handbook. Testing took place under speeded power conditions, which means that time limits applied were generous (97\% of the participants worked on the last test item). Correlations with mathematics achievement were $r=.56$ for teacher-assigned grades and $r=.58$ for scores on the mathematics achievement test described below $(N=2,059)$. Sample alpha was 92 .

Mathematics achievement. To assess students' performance in mathematics, a 63-item test based on the concept of mathematical literacy (OECD, 2003) was developed as part of the PALMA study (vom Hofe, Pekrun, Kleine, \& Goetz, 2002). In line with the concept of mathematical literacy, the test measures students' ability to recognize and interpret mathematical problems encountered in their world, translate these problems into a mathematical context, use mathematical knowledge and procedures to solve the problems, interpret the results in terms of the original problem, reflect on the methods applied, and communicate the outcomes.

Analyses were based on a total test score derived from the subscales quantity, change and relationship, shape and space, and computation. The test is presented in paper-and-pencil format and scaled according to the Rasch model (Likelihood Ratio Test: $\lambda=2.14 \times 10^{-21}$, 
$n s$; cf. Anderson, 1973; Embretson \& Reise, 2000). The mean total score was set to 100 and the standard deviation to 10. Testing took place under speeded power conditions. Teacher-assigned school grades in mathematics were used as a second indicator of achievement.

Academic self-concept in mathematics. Six items of the German version of the Sears Self-Concept Inventory (Ewert, 1979) were adapted for the assessment of academic self-concept in mathematics (e.g., "It is easy for me to solve mathematical problems"). Participants responded on a Likert scale from 1 (strongly disagree) to 5 (strongly agree). Responses were summed and averaged by the number of items $(M=3.34 ; S D=.88)$. Sample reliability was alpha $=.90$. In a preliminary study $(N=505)$, we found a disattenuated correlation of $r=.91$ between this scale and the German short version of the mathematics-related academic self-concept scale of the Self Description Questionnaire developed by Marsh (1988; sample item: "I get good marks in mathematics"). This correlation with the Self Description Questionnaire self-concept scale offers concurrent validity evidence for the academic self-concept scale.

Interest in mathematics. Interest in mathematics was assessed with a six-item scale addressing interest in subject ("I am interested in mathematics," "I like dealing with books or teasers which are related to mathematics," "Future math-related employment is something that interests me"), and classroom instruction ("I often think that what we are talking about in my math class is really exciting," "After math class I am often already curious about the next math class," "I would like to deal more intensively with some topics discussed in my math class") (vom Hofe et al., 2002). Respondents answered on a Likert scale from 1 (strongly disagree) to 5 (strongly disagree). Responses to items were summed and averaged by total item number $(M=$ 2.62; $S D=.99), \alpha=.88$. The disattenuated sample correlation of the interest scale with the enjoyment scale of the Achievement Emotions QuestionnaireMathematics (Pekrun, Goetz, \& Frenzel, 2005) assessing enjoyment in math classes was $r=.89$, providing concurrent validity evidence for the scale.

Motivation. For assessing mastery goals in mathematics, the two items from Elliot and McGregor's (2001) Achievement Goals Questionnaire were modified for the purposes of this study: "I want to learn as much as possible from my math class" and "In my math class I make an effort because I would like to be competent in this subject." Respondents responded on a 1 (strongly disagree) to 5 (strongly disagree) scale. Responses to items were summed and averaged by total item number $(M=3.27 ; S D=.98)$. Sample reliability was $\alpha=.65$.

The eight items assessing performance goals in mathematics were also constructed by modifying items from Elliot and McGregor's (2001) Achievement Goals Questionnaire (sample items: "It is important for me to do well in math class compared to others," "I work hard in mathematics because I want to get good grades"). Respondents answered on the same Likert scale described above. Responses to items were summed and averaged by total item number $(M=3.22 ; S D=.84)$. Sample reliability was $\alpha=.85$.

\section{Procedure}

Participants were recruited and data were collected by the Data Processing Center of the International Association for the Evaluation of Educational Achievement. Participants were tested in class and took part on a voluntary basis. An experimenter was present throughout the entire testing session, which lasted approximately 180 minutes, including short breaks. Instructions were given in print as well as verbally by the experimenters. Students completed the intelligence test, the mathematics achievement test, and a self-report questionnaire including the scales described above, in this order.

\section{Data Analysis}

Means and standard deviations for average-ability girls' and boys' achievement (grades and test scores), self-concept, interest, and motivation (mastery and performance goal orientation) in mathematics were calculated first. School grades were $z$ standardized within subsamples of participants attending the three tracks of the German school system. In addition, because German grades range from 1 (high achievement) to 6 (low achievement), scores were reversed such that low values indicate low achievement and high values high achievement.

Second, group and gender differences with respect to grades, test scores, self-concept, interest, mastery goal orientation, and performance goal orientation in mathematics were analyzed by separate analyses of variance with repeated measures. Repeated measures analysis of variance was used because of the structure of this data set (dependent data in the average-ability sample due to the procedure of drawing this sample). 
Table 2

Means, Standard Deviations, and Effect Sizes for the Comparison of Achievement (Grades and Test Scores), Self-Concept, Interest, Mastery Goal Orientation, and Performance Goal Orientation in Mathematics Between Gifted and Average-Ability Girls and Boys

\begin{tabular}{|c|c|c|c|c|c|c|c|c|c|c|c|c|}
\hline \multirow[b]{3}{*}{ Math-Related Measures } & \multicolumn{6}{|c|}{ Gifted } & \multicolumn{6}{|c|}{ Average Ability } \\
\hline & \multicolumn{2}{|c|}{ Whole Group } & \multicolumn{2}{|c|}{ Female } & \multicolumn{2}{|c|}{ Male } & \multicolumn{2}{|c|}{ Whole Group } & \multicolumn{2}{|c|}{ Female } & \multicolumn{2}{|c|}{ Male } \\
\hline & $M$ & $S D$ & $M$ & $S D$ & $M$ & $S D$ & $M$ & $S D$ & $M$ & $S D$ & $M$ & $S D$ \\
\hline Grade $^{a}$ & 0.24 & 0.95 & 0.15 & 0.97 & 0.33 & 0.92 & -0.24 & 0.99 & -0.22 & 0.91 & -0.26 & 1.06 \\
\hline Achievement test ${ }^{\mathrm{b}}$ & 108.32 & 8.82 & 105.63 & 7.48 & 110.92 & 9.27 & 102.67 & 8.31 & 101.39 & 7.21 & 103.91 & 9.12 \\
\hline Academic self-concept ${ }^{c}$ & 3.54 & 0.92 & 3.23 & 0.90 & 3.83 & 0.84 & 3.15 & 0.82 & 3.03 & 0.84 & 3.26 & 0.76 \\
\hline Interest $^{\mathrm{d}}$ & 2.76 & 1.07 & 2.36 & 0.99 & 3.13 & 1.02 & 2.50 & 0.88 & 2.36 & 0.87 & 2.60 & 0.88 \\
\hline Mastery goal orientation ${ }^{\mathrm{e}}$ & 3.35 & 1.02 & 3.11 & 0.96 & 3.54 & 1.03 & 3.21 & 0.95 & 3.17 & 0.88 & 3.23 & 1.00 \\
\hline Performance goal orientation ${ }^{f}$ & 3.28 & 0.91 & 3.07 & 0.89 & 3.44 & 0.85 & 3.18 & 0.75 & 3.03 & 0.76 & 3.33 & 0.77 \\
\hline
\end{tabular}

Note: Differences in $n$ are due to missing data. Responses to Likert items for rows for academic self-concept, interest, mastery goal orientation, and performance goal orientation were summed and averaged by number of items per scale.

${ }^{a}$ Grades were $z$ standardized within school types; higher values indicate better grades; $n=89$ female, 92 male in each group.

${ }^{\mathrm{b}} n=89$ female, 91 male in each group.

${ }^{c} n=80$ female, 82 male in each group.

${ }^{\mathrm{d}} n=84$ female, 87 male in each group.

${ }^{\mathrm{e}} n=85$ female, 88 male in each group.

$\mathrm{f}_{n}=74$ female, 79 male in each group.

\section{Results}

The gifted students showed higher achievement in mathematics than did the average-ability students. In line with Hypotheses $1 \mathrm{a}$ and $1 \mathrm{~b}$, there were no significant gender differences in mathematics grades, but there were significant test score differences in favor of the boys in both gifted and average-ability students $(d=.66$; see Tables 2 and 3$)$. In accordance with Hypothesis 2, gifted girls as well as girls of average ability showed lower levels of self-concept and interest in mathematics than did their male counterparts. In addition, contrary to expectations, there also was a significant main effect of gender for mastery goal orientation (lower scores for mastery orientation in girls); however, this effect was small $(d=-.25)$. Similarly, the scores for performance goal orientation were lower for girls than for boys.

For all of the measures of self-concept, interest, and motivation, gender differences were larger for gifted than for average-ability students (see Table 2 and Figure 1). Gifted boys got higher scores for these variables than did gifted girls but gender differences in the group of average-ability students were small. The interaction of ability and gender was significant for all of these variables, with the exception of performance goal orientation (Table 3 ).

In addition, there were significant main effects of ability group for self-concept and interest, with higher values for the gifted group. However, these main effects of ability group were primarily produced by the data of the gifted boys, as indicated by the significant interaction of ability group and gender noted above (see Table 3 and Figure 1). Gifted boys got significantly higher scores for self-concept and interest than did both boys and girls of average ability (all $p<.01$ ). The scores for gifted girls, on the other hand, were similar to the scores for girls of average ability. Mastery goal orientation and performance goal orientation did not differ significantly between ability groups. As noted, gifted boys gave significantly higher ratings for mastery goal orientation than did gifted girls but there were no gender differences within the group of average ability. For performance goal orientation, girls showed lower performance goal orientation than did boys, independent of ability level.

\section{Discussion}

This study investigated gender differences in gifted sixth graders, as compared with gender differences in a parallel sample of average-ability students, with respect to achievement, self-concept, interest, and motivation in mathematics. In contrast to many previous studies on the gifted, the sample of gifted students was drawn from an unselected student sample. It is reasonable to assume that most of these gifted students were not identified as being gifted and 
Table 3

Results of the Analyses of Variance With Repeated Measures Testing the Effects of Giftedness and Gender on Achievement (Grades and Test Scores), Self-Concept, Interest, Mastery Goal Orientation, and Performance Goal Orientation in Mathematics

\begin{tabular}{|c|c|c|c|c|c|c|c|c|c|c|c|c|}
\hline & \multicolumn{2}{|c|}{$\begin{array}{c}\text { Grade } \\
(n=179)\end{array}$} & \multicolumn{2}{|c|}{$\begin{array}{c}\text { Achievement } \\
\text { Test }(n=181)\end{array}$} & \multicolumn{2}{|c|}{$\begin{array}{l}\text { Academic } \\
\text { Self-Concept } \\
(n=162)\end{array}$} & \multicolumn{2}{|c|}{$\begin{array}{l}\text { Interest } \\
(n=171)\end{array}$} & \multicolumn{2}{|c|}{$\begin{array}{c}\text { Mastery } \\
\text { Goal } \\
\text { Orientation } \\
(n=174)\end{array}$} & \multicolumn{2}{|c|}{$\begin{array}{c}\text { Performance } \\
\text { Goal } \\
\text { Orientation } \\
(n=153)\end{array}$} \\
\hline & $F$ & $p$ & $F$ & $p$ & $F$ & $p$ & $F$ & $p$ & $F$ & $p$ & $F$ & $p$ \\
\hline Ability group & 24.88 & $<.001$ & 53.20 & $<.001$ & 16.98 & $<.001$ & 7.29 & $<.01$ & 1.83 & .18 & 1.34 & .25 \\
\hline Gender & 0.42 & .52 & 14.98 & $<.001$ & 21.31 & $<.001$ & 21.24 & $<.001$ & 4.83 & $<.05$ & 9.35 & $<.01$ \\
\hline Ability Group $\times$ Gender & 1.35 & .25 & 3.91 & .05 & 5.59 & $<.05$ & 8.22 & $<.01$ & 3.95 & $<.05$ & 0.43 & .51 \\
\hline
\end{tabular}

Note: Differences in $n$ are due to missing data.

Figure 1

Differences in Achievement, Self-Concept, Interest, and Motivation in Mathematics Between Gifted and Average-Ability Girls and Boys
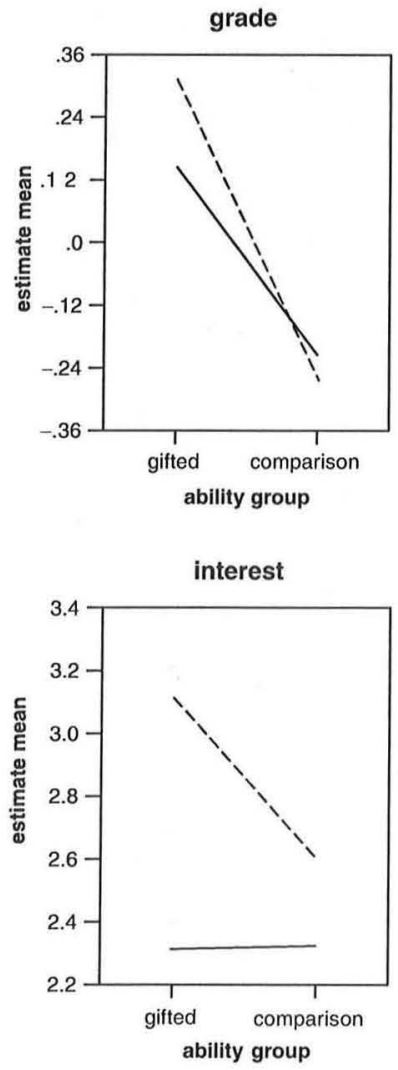
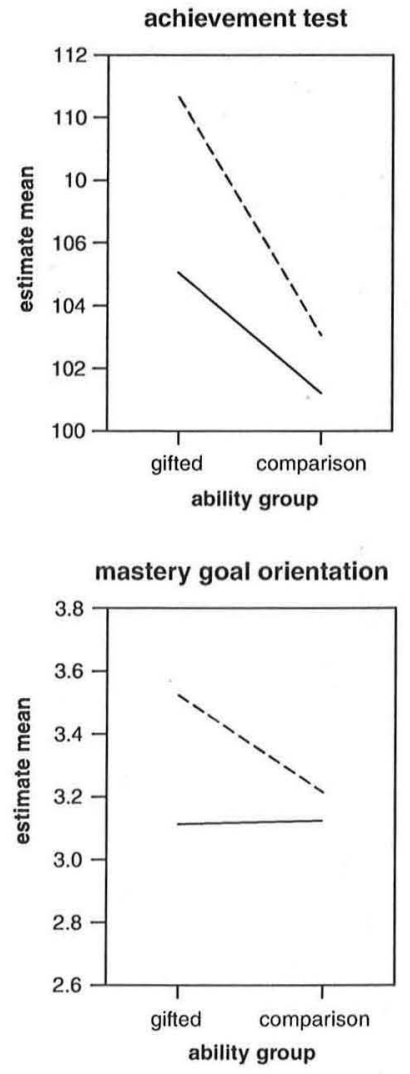

female $\quad$.......... male
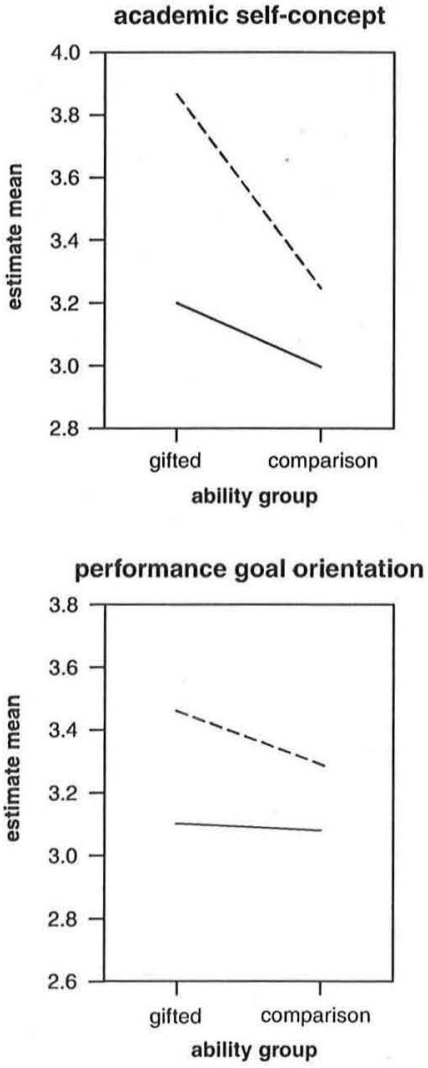
did not receive specialized fostering options. This assumption is supported by the finding that nearly $44 \%$ of the gifted students attended the mediumor low-level school tracks. In accordance with former studies (e.g., Roznowski et al., 2000), we found that the gifted, on average, came from families with higher than average SES.

On average, the gifted students clearly outperformed their nongifted counterparts with respect to achievement in mathematics (i.e., grades and scores on a standardized mathematics test). In line with expectations, gifted females and males had equally good grades in math. However, as expected, gifted males performed better on a test of mathematical literacy than did their female counterparts. Thus, findings documented in many Western countries for samples of the general population were confirmed here for the gifted. For averageability students as well, findings of this study are in line with previous findings, showing comparable grades but lower mathematical literacy scores for average-ability female students as compared to average-ability male students.

The higher scores of males on the test of mathematical literacy can be explained to some extent by the male advantage in mathematical problem solving (Benbow \& Lubinski, 1993; Hyde et al., 1990; see also Nuttal, Casey, \& Pezaris, 2004, for a discussion of the influence of spatial ability on mathematics performance). However, gender differences in mathematical problemsolving show substantial cross-cultural variation. Therefore, in accordance with theoretical approaches such as the Eccles (1983) model, it is reasonable to assume that achievement differences in mathematical literacy are primarily caused by gender-role socialization practices as well as by teacher and parent expectations. These practices and expectations can be assumed to shape the development of achievement-related motivational traits (such as academic self-concept, interest, and goal orientations) that influence students' development of mathematical competences.

Similarly, as to the development of gender differences in mathematics-related self-concept, interest, and motivation, it can be assumed that socialization practices relating to gender roles are more important than cognitive ability. Our results are consistent with this assumption. Girls in both ability groups showed lower levels of self-concept, interest, and motivation (mastery and performance goal orientation) in mathematics than did their male counterparts.

However, for all of these affective variables, gender differences were larger in the sample of gifted students than in the sample of average-ability students. The interactions between ability group and gender were significant for self-concept, interest, and mastery goal orientation. These striking, unexpected interactions of ability group and gender imply that gender differences in attitudes toward mathematics are even stronger in gifted students than in the general population. Using the Eccles (1983) model of achievement-related socialization, this finding might be explained by assuming that gender-linked socialization practices relating to academic domains are more powerful when applied to gifted students as compared to average-ability students.

For example, it might be that gifted students are more aware of their aptitudes, and of social expectations how to use these aptitudes, such that gender-role stereotypes and the gender-linked development of academic motivation become more pronounced in this group of students. By implication, it may be that gifted girls, more so than average-ability girls, tend to develop and use their abilities only if type of ability and gender-linked social expectations are congruent to each other, which may contribute to explaining why there is such a dramatic loss of female talent in the domains of mathematics, the inorganic sciences, and engineering.

\section{Limitations}

Study limitations can be used to derive suggestions for future research. For reasons outlined in the method section, this study used a narrow definition of giftedness; that is, we chose nonverbal reasoning ability as the single criterion for defining the samples of gifted and average-ability students in our investigation. This should be kept in mind when comparing our results with findings derived from other studies. Also, our study focused exclusively on the domain of mathematics. The gender differences as analyzed in this study should be investigated in other domains such as science or verbal subjects.

Furthermore, the self-concept, interest, and motivation measures employed in our study were self-report in nature. Instead of actually experiencing different levels of motivation, male and female students may differ in their ability and willingness to express their motivational beliefs (see Grossman \& Wood, 1993, for differences relating to affective experiences). By implication, males' and females' self-reports might have been influenced by factors such as social desirability and stereotyping. 
Furthermore, when interpreting the findings of this study, it should be taken into account that the sample consisted of 6th-grade German students. Further studies are needed to investigate whether our findings can be replicated in other cultures and in students of different ages. However, as noted, these results on differences between gifted and average-ability students as well as the findings on gender differences in average-ability students are similar to those found in previous research that used samples from different cultures and age groups. Thus, it can reasonably be assumed that it should prove possible to generalize the present findings on gender differences in gifted students to other age groups and types of students.

\section{Conclusion}

Gender differences in mathematics-related attitudes (self-concept, interest, and motivation) in favor of male students were substantially larger in gifted students as compared to average-ability students. Also, mathematicsrelated self-concept and interest differed in male students of different ability, whereas ability group did not explain the variance of attitudes in female students. For example, we found no differences in the mathrelated self-concepts of gifted and average-ability girls. Females tend to estimate their mathematical competence lower than their male counterparts do-and the gifted females in our study were no exception, in spite of the fact that they earned equally good math grades as the gifted boys.

Recent research has investigated the linkages of competence beliefs with interest development, motivation, and affect (e.g., Pekrun, 1993; Todt \& Schreiber, 1998), and evidence is accumulating that the relationships between these constructs are reciprocal (e.g., Byrne \& Gavin, 1996; Hannover, 1998; Pekrun, 1992), thus sustaining converging developments over the school years. In accordance with assumptions on convergence of different attitudinal variables, we found a consistent pattern of unfavorable mathematics-related attitudes in girls and a consistent pattern of more favorable attitudes in boys. The disadvantageous attitudes found for girs, including gifted girls, likely reduce the probability for high achievement and high participation rates of girls in the domain of mathematics and related fields (Eccles \& Harold, 1992).

In a review of the literature on factors influencing the realization of high mathematical abilities in girls,
Le Maistre and Kanevsky (1996) concluded that a combination of interventions is required to foster gifted girls' development in mathematics. Gender differences in math-related competence beliefs in favor of boys have been documented as early as in the first grade. Therefore, early identification of abilities as well as early intervention is crucial to reduce the likelihood that girls develop disadvantageous self-perceptions and negative attitudes toward mathematics. Interventions should not only focus on the girl herself but should also address environmental factors such as parents, teachers, peer groups, and administrative planning (J. Freeman, 2004). Possible interventions include programs for enhancing interest by single-sex education, changes of curricula and classroom instruction (Baumert \& Köller, 1998; J. Freeman, 2004), enhancing the number of math courses for female students (Eccles, 1987; see also Kerr \& Robinson Kurpius, 2004, who developed a 1-day intervention program for mathematically and scientifically talented girls who are at risk for dropping out of the math-science field), attributional retraining (Heller \& Ziegler, 1996), provision of role models and mentoring (Le Maistre \& Kanevsky, 1996), and teacher and parent counselling (Le Maistre \& Kanevsky, 1996). The findings of this study confirm the need for such programs and interventions for girls, particularly girls of high ability.

Support should not pursue the goal of enforcing equal representations of males and females in the domains of mathematics, science, and engineering but rather make it possible that the genders will be more equally represented in these domains in the future. Gifted females need better conditions that allow them to develop more functional self-perceptions of mathematical abilities and more interest in mathematics so that they can make well-advised decisions for or against educational and occupational careers in these domains.

\section{Notes}

1. This analysis is based on data from the Project for the Analysis of Learning and Achievement in Mathematics (Pekrun et al., 2004; Zirngibl, Pekrun, Goetz, \& Perry, 2005), a longitudinal study analyzing the development of mathematics-related competence and affect as well as instructional and family antecedents of this development, in a representative sample of Bavarian secondary school students.

2. For the revised version, item difficulty was increased. In this version, item difficulty is determined by item complexity (complexity of relations between figural elements) instead of precision of perception or ability to discriminate between figural stimuli. 


\section{References}

Achter, J. A., Lubinski, D., \& Benbow, C. P. (1996). Multipotentiality among intellectually gifted: "It was never there and already it's vanishing."Journal of Counseling Psychology, 43, 65-76.

Anderson, E. B. (1973). A goodness of fit test for the Raschmodel. Psychometrika, 38, 123-140.

Baumert, J., Bos, W., \& Lehmann, R. (Eds.) (2000). TIMSS/III: Dritte Internationale Mathematik- und NaturwissenschaftsstudieMathematische und naturwissenschaftliche Bildung am Ende der Schullaufbahn [TIMSS/III: Third international mathematics and science study -Education in math and science at the end of school training]. Opladen, Germany: Leske + Budrich.

Baumert, J., \& Köller, O. (1998). Interest research in secondary level I: An overview. In L. Hoffmann, A. Krapp, K. A. Renninger, \& J. Baumert (Eds.), Interest and learning: Proceedings of the Seeon Conference on Interest and Gender (pp. 241-256). Kiel, Germany: Institut für die Pädagogik der Naturwissenschaften an der Universität Kiel.

Benbow, C. P., \& Lubinski, D. (1993). Psychological profiles of the mathematically talented: Some gender differences and evidence supporting their biological basis. In K. Ackerill (Ed.), The origins and development of high ability (pp. 44-59) [Ciba Foundation Symposium No. 178]. New York: John Wiley \& Sons.

Benbow, C. P., \& Stanley, J. C. (1983). Academic precocity: Aspects of its development. Baltimore, MD: Johns Hopkins University Press.

Brody, L. E., Barnett, L. B., \& Mills, C. J. (1994). Gender differences among talented adolescents: Research studies by SMPY and CTY at the Johns Hopkins University. In K. A. Heller \& E. A. Hany (Eds.), Competence and responsibility: Proceedings of the Third European Conference of the European Council for High Ability (pp. 204-210). Göttingen, Germany: Hogrefe.

Byrne, B. M., \& Gavin, D. A. W. (1996). The Shavelson model revisited: Testing for structure of academic self-concept across pre-, early, and late adolescents. Journal of Educational Psychology, $88,215-228$

Carroll, J. B. (1993). Human cognitive abilities: A survey of factor analytic studies. Cambridge, UK: Cambridge University Press.

Colangelo, N., Assouline, S. G., Cole, V., Cutrona, C., \& Maxey, J. E. (1996). Exceptional academic performance: Perfect scores on the PLAN. Gifted Child Quarterly, 40, 102-110.

Dawis, R. V., \& Lofquist, L. H. (1984). A psychological theory of work adjustment. Minneapolis: University of Minnesota Press.

Eccles, J. S. (1983). Expectancies, values, and academic behaviors. In J. T. Spence (Ed.), Achievement and achievement motives (pp. 75-146). San Francisco: W. H. Freeman.

Eccles, J. S. (1987). Gender roles and women's achievement-related decisions. Psychology of Women Quarterly, 11, 135-172.

Eccles, J. S. (1993). Parents as gender-role socializers during middle childhood and adolescence. New Orleans, LA: Society for Research in Child Development.

Eccles, J. S., Adler, T., \& Meece, J. L. (1984). Sex differences in achievement: A test of alternate theories. Journal of Personality and Social Psychology, 46, 26-43.

Eccles, J. S., \& Harold, R. D. (1992). Gender differences in educational and occupational patterns among the gifted. In N. Colangelo, S. G. Assouline, \& D. L. Amronson (Eds.), Talent development: Proceedings form the 1991 Henry B. and Jocelyn Wallace National Research Symposium on Talent Development (pp. 3-29). Unionville, NY: Trillium.
Eccles, J. S., Wigfield, A., Harold, R. D., \& Blumenfeld, P. (1993). Age and gender differences in children's self- and task perceptions during elementary school. Child Development, 64, 830-847.

Educational Testing Service. (1987). A summary of data collected from Graduate Record Examinations test-takers du ring 1985 86. Princeton, NJ: Author.

Elliot, A., \& Harackiewicz, J. (1996). Approach and avoidance achievement goals and intrinsic motivation: A mediational analysis. Journal of Personality and Social Psychology, 70, 968-980.

Elliot, A. J., \& McGregor, H. A. (2001). A $2 \times 2$ achievement goal framework. Journal of Personality and Social Psychology, 80, 501-519.

Embretson, S. E., \& Reise, S. P. (2000). Item response theory for psychologists. Mahwah, NJ: Erlbaum.

Enman, M., \& Lupart, J. (2000). Talented female students' resistance to science: An exploratory study of post-secondary achievement motivation, persistence, and epistemological characteristics. High Ability Studies, 11, 161-178.

Erikson, R., Goldthorpe, J., \& Portocarero, L. (1979). Intergenerational class mobility in three Western European societies: England, France and Sweden. British Journal of Sociology, 30, 415-441.

Ewert, O. (1979). Eine deutsche Version der Sears Self-concept Inventory Scale [Sears self-concept inventory scale-German version]. In S. H. Filipp (Ed.), Selbstkonzept-Forschung (pp. 191-202). Stuttgart, Germany: Klett.

Finsterwald, M., \& Ziegler, A. (2002). Geschlechtsunterschiede in der Motivation: Ist die Situation bei normal begabten und hoch begabten Schüler(inne)n gleich? [Gender differences in motivation: Is the situation comparable for gifted and nongifted female students?]. In H. Wagner (Ed.), Hoch begabte Mädchen und Frauen.Begabungsentwicklung und Geschlechtsunterschiede (pp. 67-83). Bad Honnef, Germany: Bock.

Fox, L. H., Engle, J. L., \& Paek, P. (2001). An exploratory study of social factors and mathematics achievement among highscoring students: Cross-cultural perspective from TIMSS. Gifted and Talented International, 16, 7-15.

Freeman, C. E. (2004). Trends in educational equity of girls \& women: 2004. Washington, DC: U.S. Department of Education, National Center for Education Statistics.

Freeman, J. (2003). Gender differences in gifted achievement in Britain and the U.S. Gifted Child Quarterly, 47, 202-211.

Freeman, J. (2004). Cultural influences on gifted gender achievement. High Ability Studies, 15, 7-23.

Frome, P. M., \& Eccles, J. S. (1998). Parents' influence on children's achievement-related perceptions. Journal of Personality and Social Psychology, 74, 435-452.

Gallagher, A. M., \& Kaufmann, J. C. (2005). Gender differences in mathematics: An integrative psychological approach. Cambridge, UK: Cambridge University Press.

Grossman, M., \& Wood, W. (1993). Sex differences in intensity of emotional experience: A social role interpretation. Journal of Personality and Social Psychology, 65, 1010-1022.

Halpern, D. F. (2000). Sex differences in cognitive abilities. Mahwah, NJ: Erlbaum.

Hanna, G. (2000). Declining gender differences from FIMS to TIMSS. International Reviews on Mathematical Education, 32, 11-17.

Hannover, B. (1998). The development of self-concept and interests. In L. Hoffmann, A. Krapp, K. A. Renninger, \& J. Baumert (Eds.), 
Interest and learning. Proceedings of the Seeon Conference on Interest and Gender (pp. 105-125). Kiel, Germany: Institut für die Pädagogik der Naturwissenschaften an der Universität Kiel.

Heller, K. A., \& Perleth, C. (2000). Kognitiver Fähigkeitstest für 4. bis 12. Klassen, Revision (KFT 4-12+R) [Cognitive ability test for class level 4 to 12 , revised version]. Göttingen, Germany: Hogrefe.

Heller, K. A., \& Ziegler, A. (1996). Gender differences in mathematics and the natural sciences: Can attributional retraining improve the performance of gifted females? Gifted Child Quarterly, 40, 200-210.

Hofe, R. vom, Pekrun, R., Kleine, M., \& Goetz, T. (2002). Projekt zur Analyse der Leistungsentwicklung in Mathematik (PALMA). Konstruktion des Regensburger Mathematikleistungstests für 5.10 Klassen [Project for the analysis of achievement development in mathematics: Construction of a mathematics achievement test for grades 5 to 10]. Zeitschrift für Pädagogik, 45. Beiheft. Weinheim, Germany: Beltz.

Holland, J. L. (1997). Making vocational choices: A theory of vocational personalities and work environments. Odessa, FL: Psychological Assessment Resources.

Holling, H., \& Preckel, F. (2005). Self-estimation of intelligenceMethodological approaches and gender differences. Personality and Individual Differences, 38, 503-517.

Hosenfeld, I., Köller, O., \& Baumert, J. (1999). Why sex differences in mathematics achievement disappear in German secondary schools: A reanalysis of the German TIMSS-data. Studies in Educational Evaluation, 25, 143-161.

Hyde, J. S., Fennema, E., \& Lamon, S. J. (1990). Gender differences in mathematics performance: A meta-analysis. Psychological Bulletin, 107, 139-155.

Jacobs, J. E., \& Eccles, J. S. (1992). The impact of mothers' gender-role stereotypic beliefs on mothers' and children's ability perceptions. Journal of Personality and Social Psychology, 63, 932-944.

Jäger, A. O., Holling, H., Preckel, F., Schulze, R., Vock, M., Süß, H.-M., et al. (2006). Berliner Intelligenzstruktur-Test für Jugendliche: Begabungs- und Hochbegabungsdiagnostik (BIS-HB) [Berlin structure of intelligence test for youth: Assessment of talent and giftedness]. Göttingen, Germany: Hogrefe.

Kerr, B., \& Robinson Kurpius, S. E. (2004). Encouraging talented girls in math and science: Effects of a guidance intervention. High Ability Studies, 15, 85-102.

Leahey, E., \& Guo, G. (2001). Gender differences in mathematical trajectories. Social Forces, 80, 713-732.

Leder, G. (2004). Gender differences among gifted students: Contemporary views. High Ability Studies, 15,103-108.

Le Maistre, C., \& Kanevsky, L. (1996). Factors influencing the realization of exceptional mathematical ability in girls: An analysis of the research. High Ability Studies, 8, 31-46.

Lohman, D. F. (2005). The role of nonverbal ability tests in identifying academically gifted students: An aptitude perspective. Gifted Child Quarterly, 49, 111-136.

Lubinski, D., \& Benbow, C. P. (1992). Gender differences in abilities and preferences among the gifted: Implications for the math/science pipeline. Current Directions in Psychological Science, 1, 61-66.

Lubinski, D., Benbow, C. P., \& Morelock, M. (2000). Gender differences in engineering and the physical sciences among the gifted: An inorganic-organic distinction. In K. Heller, F. Mönks,
R. Sternberg, \& R. Subotnik (Eds.), International handbook of giftedness and talent (2nd ed., pp. 633-648). Oxford, UK: Pergamon.

Lubinski, D., \& Humphreys, L. G. (1990). A broadly based analysis of mathematical giftedness. Intelligence, 14, 327-355.

Lupart, J. L., Cannon, E., \& Telfer, J. O. (2004). Gender differences in adolescent academic achievement, interests, values, and life-role expectations. High Ability Studies, 15, 25-42.

Marsh, H. W. (1988). Self description questionnaire: A theoretical and empirical basis for the measurement of multiple dimensions of preadolescent self-concept: A test manual and a research monograph. San Antonio, TX: Psychological Corporation.

Marsh, H. W. (1993). Academic self-concept: Theory measurement and research. In J. Suls (Ed.), Psychological perspectives on the self (Vol. 4, pp. 59-98). Hillsdale, NJ: Erlbaum.

Marsh, H. W., \& Yeung, A. S. (1997). Coursework selection: Relations to academic self-concept and achievement. American Educational Research Journal, 34, 691-720.

Nuttal, R. L., Casey, M. B., \& Pezaris, E. (2004). Spatial ability as mediator of gender differences on mathematical tests: A biological-environmental framework. In A. Gallager \& J. Kaufman (Eds.), Gender differences in mathematics: An integrative psychological approach (pp.121-142). Cambridge, UK: Cambridge University Press.

Organization for Economic Co-operation and Development. (2003). PISA 2003 assessment framework-Mathematics, reading, science, and problem solving knowledge and skills. Paris: Author.

Organization for Economic Co-operation and Development. (2004). Learning for tomorrow's world-First results from PISA 2003. Paris: Author.

Pajares, F., Britner, S., \& Valiante, G. (2000). Writing and science achievement goals of middle school students. Contemporary Educational Psychology, 25, 406-422.

Pajares, F., \& Miller, M. D. (1994). Role of self-efficacy and selfconcept beliefs in mathematical problem solving: A path analysis. Journal of Educational Psychology, 86, 193-203.

Pekrun, R. (1992). The expectancy-value theory of anxiety: Overview and implications. In D. G. Forgays, T. Sosnowski, \& K. Wrzesniewski (Eds.), Anxiety: Recent developments in self-appraisal, psychophysiological and health research (pp. 23-41). Washington, DC: Hemisphere.

Pekrun, R. (1993). Facets of students' academic motivation: A longitudinal expectancy-value approach. In M. Maehr \& P. Pintrich (Eds.), Advances in motivation and achievement (Vol. 8, pp. 139-189). Greenwich, CT: JAI.

Pekrun, R., Goetz, T., \& Frenzel, A. C. (2005). Achievement Emotions Questionnaire-Mathematics (AEQ-M)-User's manual. Munich, Germany: University of Munich.

Pekrun, R., Goetz, T., vom Hofe, R., Blum, W., Jullien, S., Zirngibl, A., et al.. (2004). Emotionen und Leistung im Fach Mathematik: Ziele und erste Befunde aus dem Projekt zur Analyse der Leistungsentwicklung in Mathematik (PALMA) [Emotions and achievement in mathematics: Aims and first results of the Project for the Analysis of Learning and Achievement in Mathematics (PALMA)]. In J. Doll \& M. Prenzel (Eds.), Bildungsqualität von Schule: Lehrerprofessionalisierung, Unterrichtsentwicklung und Schülerförderung als Strategien der Qualitätsverbesserung (pp. 345-363). Münster, Germany: Waxmann.

Pekrun, R., \& Zirngibl, A. (2004). Schülermerkmale im Fach Mathematik [Student characteristics in mathematics]. In 
M. Prenzel, J. Baumert, W. Blum, R. Lehmann, D. Leutner, M. Neubrand, R. Pekrun, H.-G. Rolff, J. Rost, \& U. Schiefele (Eds.), PISA 2003. Der Bildungsstand der Jugendlichen in Deutschland - Ergebnisse des zweiten internationalen Vergleichs (pp. 191-210). Münster, Germany: Waxmann.

Preckel, F., \& Thiemann, H. (2003). Online- versus paper-pencilversion of a high potential intelligence test. Swiss Journal of Psychology, 62, 131-138.

Roznowski, M., Reith, J., \& Hong, S. (2000). A further look at youth intellectual giftedness and its correlates: Values, interests, performance, and behavior. Intelligence, 28, 87-113.

Schober, B., Reimann, R., \& Wagner, P. (2004). Is research on gender-specific underachievement in gifted girls an obsolete topic? New findings on an often discussed issue. High Ability Studies, 15, 43-62.

Skaalvik, S., \& Skaalvik, E. M. (2004). Gender differences in math and verbal self-concept, performance expectations, and motivation. Sex Roles: A Journal of Research, 50, 241-252.

Sternberg, R. J., \& Davidson, J. (2005). Conceptions of giftedness (2nd ed.). Cambridge, UK: Cambridge University Press.

Stumpf, H., \& Stanley, J. C. (1998). Stability and change in gender-related differences on the college board advanced placement and achievement tests. Current Directions in Psychological Science, 7, 192-196.

Terwilliger, J., \& Titus, J. (1995). Gender differences in attitudes and attitude changes among mathematically talented youth. Gifted Child Quarterly, 39, 29-35.

Thorndike, R. L., \& Hagen, E. (1971). Cognitive abilities test. Boston: Houghton-Mifflin.

Todt, E., \& Schreiber, S. (1998). Development of interests. In L. Hoffmann, A. Krapp, K. A. Renninger, \& J. Baumert (1998), Interest and learning: Proceedings of the Seeon Conference on Interest and Gender (pp. 25-40). Kiel, Germany: Institut für die Pädagogik der Naturwissenschaften an der Universität Kiel.

Wigfield, A., Eccles, J. S., Suk Yoon, K., Harold, R. D., Arbreton, A. J. A., Freedman-Doan, C., et al. (1997). Change in children's competence beliefs and subjective task values across the elementary school years: A 3-year study. Journal of Educational Psychology, 89, 451-469.

Wilgenbusch, T., \& Merrill, K. W. (1999). Gender differences in self-concept among children and adolescents: A meta-analysis of multidimensional studies. School Psychology Quarterly, $14,101-120$

Ziegler, A. (2004). Gifted females in mathematics, the natural sciences and technology [Special Issue]. High Ability Studies, 15.

Ziegler, A., Heller, K. A., \& Broome, P. (1996). Motivational preconditions for girls gifted and highly gifted in physics. High Ability Studies, 7, 129-144.

Zirngibl, A., Pekrun, R., Goetz, T., \& Perry, R. P. (2005, April). Girls and mathematics-A hopeless issue? An analysis of girls' and boys' emotional experiences in mathematics. Paper presented at the annual meeting of the American Educational Research Association, Montreal, Canada.

Zorman, R., \& David, H. (2000). Female achievement and challenges towards the third millenium. Jerusalem, Israel: Henrietta Szold Institute Press.

Franzis Preckel is a full professor of psychology at the University of Trier and is Chair of Giftedness Research and Education. Her main research interests include intelligence, test development, assessment of giftedness, and counseling in gifted education.

Thomas Goetz holds a full professorship in psychology and teaches both at the University of Konstanz and the Thurgau University of Teacher Education. His main research topics include achievement emotions, self-concepts, and self-regulated learning.

Reinhard Pekrun is a full professor of psychology and is the Vice President of Research at the University of Munich. He is a member of the German consortium for the Programme for International Student Assessment (2003 and 2006). His main research interests pertain to achievement emotion and motivation, students' personality development, educational assessment, and quality monitoring of educational systems.

Michael Kleine was a teacher of mathematics and physics, and he has been working as an assistant professor for mathematics education at the University of Regensburg since 2000. His main research interests include large-scale assessment, development of competencies in mathematics, and mental models in mathematics. 